\title{
Open
}

\section{Spinoza and constituent power}

\author{
Filippo Del Lucchese $\mathrm{a}^{\mathrm{a}, \mathrm{b}}$ \\ ${ }^{a}$ Brunel University, Uxbridge UB8 3PH, UK. \\ ${ }^{\mathrm{b}}$ University of Johannesburg, Auckland Park, 2006 South Africa.
}

\begin{abstract}
This article considers Baruch Spinoza's contribution to a theory of constituent power. Modern theories of constituent power generally agree on its paradoxical essence: a power that comes before the law and founds the law is at the same time a power that, once the juridical sphere is established, has to be obliterated by the law. Spinoza's ontology has been recognised as one of the early modern sources of constituent power, yet he argues for a strict equivalence between law and power. This article argues that by reading Spinoza's political theory through the lens of a radical immanence between ontology and history, we can understand him as a source for a theory of constituent power. It also argues that, through this immanence, Spinoza's thought offers a solution to the paradox of constituent power and enriches contemporary discussions on the origin of juridical sphere and the relationship between politics and law.
\end{abstract}

Contemporary Political Theory (2016) 15, 182-204. doi:10.1057/cpt.2015.39;

published online 7 July 2015

Keywords: constituent power; conflict; law; state theory; constitutionalism; democracy

The online version of this article is available Open Access

Since the foundation of early modern sovereignty, juridical science has tackled the problem of establishing a solid ground for authority. However, far from finding a stable solution, the problem has become more serious during the centuries of bourgeois revolutions, when new forms of power took the place of older ones and the search for a new foundation began in the nature and attributes of the new revolutionary subjects. This problem has gradually assumed a definite legal form and has taken the name of 'constituent power'. By constituent power, modern juridical science means the factual and political power that establishes a new legal order, assigning to it validity and efficacy. The constituent power is therefore pre-ordered and super-ordered vis-à-vis the constituted power: it founds and precedes the establishment of law.

Modern scholars who, especially after World War II, have developed this concept, highlight the ambiguous (Böckenförde, 1991), extreme (Schmitt, 2008) and seemingly contradictory (Mortati, 1972) character of constituent power. 
According to these authors, in fact, constituent power makes the foundation of law problematic because it makes the unresolved tension between the factual and political moment on one side and the normative and legal moment on the other visible. The origin and foundation of constituted power is in the constituent power and yet, by definition, the former obliterates the latter within the legal sphere in which it establishes itself as the only valid and recognised source of authority. To be recognised as the sole source of authority, constituted power must necessarily eliminate any other form of power.

The paradox, then, concerns the origin of the legal sphere and the relationship between the constituent and constituted moments. Positive law needs an extra-legal and normative power for its foundation. However, this source is factual and political and has no other force than the force with which it has established itself over and against the constituted power that historically precedes it and that it has destroyed, possibly with violence. In addition, once established and recognised, positive law cannot tolerate the existence of its source because it must remain the sole source of legitimacy: the creature must therefore necessarily kill its creator. Yet where does it find the necessary force to accomplish this parricide?

It is indeed a problem of force. Or, to phrase it better, a problem concerning the complex and multifarious phenomenology of force and its re-appearance in a domain which it was supposed to be expunged from, sublimated into or replaced by other mechanisms of interaction among individuals or groups. In the constitutional framework, these mechanisms are articulated within the law, and yet they constantly tend to question the law, to disrupt it and ultimately to confront it in a dynamic that threatens to re-open the initial wound of politics, and sometimes actually does so, especially in our plural and globalised world, at various degrees of intensity: dispute, conflict, rebellion, insurrection, revolution.

It is thus understandable that one of the major concerns of contemporary political theory has been to offer a fresh reading of this ancient problem, namely the (re-) emergence, within politics, of the conflictual other from which politics itself originated, through a deep renewal of the reflection on constituent power. I am interested in particular in three different strategies that scholars have pursued in recent years: the clarification of the conceptual paradoxes of constituent power itself, the redefinition of the people as political actor with factual and juridical prerogatives, and, finally, the re-invigoration of the concept of democracy, in particular through the idea of 'agonistic democracy'.

Pursuing the first strategy, Colón-Ríos has recently undertaken an explanatory analysis of constituent power, breaking down its theoretical definition into no less than five different meanings and concepts (Colón-Ríos, 2012; see also Colón-Ríos, 2014). Together, these five meanings highlight the dynamic between, on the one hand, the constituent power's institutionalisation into a particular political subject, and the contrary force exerted against this same subject, under the pressure of new social forces, on the other. Colón-Ríos's taxonomy sees constituent power first and 
foremost as a 'transformative impulse' that increases the subjects' political power, as an intrinsically destabilising element. The same taxonomy, however, tends to be too inclusive, and suggests that every power, including parliamentary sovereignty or the right to instruct representatives, somehow prolongs the constituent moment into the sphere of ordinary politics, thus losing sight of what is radically peculiar and paradoxical in the idea of constituent power itself.

Martin Loughlin underlines this paradoxical nature as the key feature of constituent power. Like Colón-Ríos, Loughlin reads constituent power as a living force that goes beyond the founding moment of the juridical community; he emphasises the always provisional quality of the legal and political domain (Loughlin and Walker, 2007; see also Loughlin, 2014). Loughlin's claim is that constituent power can be revitalised as a political tool by framing it in a relationalist approach, as distinct from the two main juridical traditions that had previously appropriated the concept, namely legal normativism à la Kelsen and legal decisionism à la Schmitt. In the attempt to avoid an excessively radical conception of politics and following Hermann Heller's legal philosophy, however, Loughlin's relationalism grants space for conflict only as a common foundation for discussion among political contenders, based on fair play, thus overlooking the main problem that Machiavelli and Spinoza had already pointed out at the dawn of modernity, namely that of tolerating radical, substantial and ultimately intolerable conflicts (Del Lucchese, 2014a).

The weakness of legal normativism in the face of the radical challenges to contemporary political life has been widely recognised, not only through a sound elucidation of Kelsen normativism, but also through solid criticism of more recent neo-Kantian approaches. Decisionism, however, is recognised as an ineliminable feature of constituent power, through the logic of a founding dimension, seen, for example, in the work of Andreas Kalyvas. Kalyvas (2005) maintains that constituent power is the radical truth of modern democracy, a truth that unveils the ideal of popular self-government beyond and against the paradigm of State sovereignty. Only by virtue of the collective dimension of the foundation can one distinguish a legitimate constitution from an illegitimate imposition of might that has been disguised as right. Eclectically echoing Hannah Arendt and Carl Schmitt, Kalyvas's approach functions mainly as an extrinsic tool of judgment of the legitimacy of constitutional frameworks. Constituent power becomes not only the 'radical truth', but also the radical origin of the people's foundation, but this, however, leaves unquestioned the political ontology of the people itself: what is $a$ people? Who are the people? What is the nature of the conflicts that traverse the people and constantly redefine its unity?

The concept of the people has been scrutinised more recently by Frank, who underlines its twofold and ambiguous status, as both a ground of and at the same time a threat to the political (Frank, 2010, p. 7), as a subject that transcends politics, but whose origin is by definition immanent (Frank, 2010, p. 9). Through a critique of both conservative and liberal readings, Frank claims that neither the constituent nor 
the constituted dimension of the people can or should obliterate its fundamental ambiguity. Such an ambiguity reveals itself throughout history in theory, and often against theory itself, as, for example, Hannah Arendt's inaccurate reading of the American revolution reveals.

I find Frank's claim about the necessity to reintroduce history (as well as other cultural fields such as literature) into theory not only important, but also essential to avoid the schematisations and shortcuts that political theorists often indulge in. At the same time, I am not convinced, as Frank suggests, that the modern history of constitutional moments begins in the last quarter of the eighteenth century, in particular with the American Revolution and constitutional history. I will show in this article that the seventeenth century's political, philosophical and legal debates cast their shadow upon political modernity in the west. From within, but largely against, this modernity, Spinoza in particular already speaks of and addresses many of the concerns that the early constitutional history of the United States, as well as of revolutionary France, will eventually make visible in legal theory.

The dialectic between history and theory is also at the heart of Näsström's (2007) analysis of the people's legitimacy in the age of globalisation. Against a substantialisation of the demos as a pre-condition of democracy, Näsström claims that the people is and should be subject to a process of legitimisation as much as its 'others' are. The people does not pre-date the space of politics from which it is, alone, entitled to include or exclude individuals or groups with their own claims and demands. Only in this way, Näsström maintains, can theory help us avoid the pure factuality of history, which it does by keeping open a normative dimension that functions as a regulatory mechanism for a fairer definition of democracy.

Without questioning the legitimacy of the people, its decision regarding the inclusion/ exclusion of other individuals and groups claims the character of absolute justice. Yet this character is only historically grounded, and it springs out of the contingencies of history. For Näsström, only a normative theory can give the people the legitimacy to make these decisions while at the same time keeping its definition, status and boundaries open to otherness, to other subjects and their demands. Näsström's theory seems to adhere to a principle of unconditional openness with which she trumps every attempt to use closure as a constitutive element of legitimacy. However, Näsström is obliged to recognise a non-negotiable principle that precedes every process of (re-) definition of the people's boundaries. This is the 'principle of consent that the disagreement on the constitution of the people has productive force' (Näsström, p. 627), to which every political actor must adhere. The horizontal character of democracy as a process depending on the openness of the people is thus weakened by the necessity of admitting a vertical principle that guides the process itself from above. Paradoxically, the principle of unconditional openness of democracy as a process must be closed, so as to be saved by democracy itself.

The question of democratic openness also drives Keenan's (2003) analysis. In an age in which the original force of democracy is ruled out by the force of the market 
under the homogenising umbrella of the dominant Western ideologies, it is more than ever necessary to recover the meaning of politics as a fully open space: one in which not only political decisions are taken by the people, but in which the people's status is also incessantly questioned by the actual practices of democracy. Like Näsström, Keenan is committed to a principle of openness as a promise of fairness and justice within a progressive concept of democracy. As with Näsström, though, such a promise becomes a premise, namely a guiding principle outside of which there is no democracy and not even politics at all: echoing (without quoting) the seventeenthcentury legal language and the seventeenth-century critics of Spinoza, Keenan argues that the people is legitimate only when it places the common good at the heart of politics; or, otherwise, it is nothing more than a multitude of individuals.

The most elaborate attempt, in recent years, to tackle the issue of the conflictual origin and nature of politics has been developed by the theorists who advocate a form of radical or agonistic democracy in our pluralist societies. Although not always synonymous, radical and agonist democracy have tried to challenge the mainstream liberal political theory, in particular in the deliberative, dialogical and consensual versions, largely associated with Jürgen Habermas, John Rawls and Seyla Benhabib.

Honig (2009), for example, has developed this critique through the idea of emergency politics. The foundation of this idea is her critique of post-Kantian deliberative theories of a rational and discursive construction of the political community as a space purified by the contingencies that continually disrupt political order (Honig, 1993). Honig has challenged the conclusion that the people, as the main subject of democracy, is either one, coherently united and consistently unified, or a multitude, a scattered mass of individuals. Honig unfolds her agonistic perspective via a valorisation of contention as a positive and generative resource for politics.

The paradox of democracy is in fact represented, for Honig (2009), by the essential undecidability of the people, both in terms of its character and its boundaries. This character of undecidability of the people has consequences that characterise not only the initial moment of political foundation, but also the entirety of political. This is among Honig's most original moves, but it is also Spinoza's move, as I will show in my article. What Honig calls the paradox of politics has already been tackled by Spinoza when he thinks politics as the never-ending process of auto-organisation of the multitude against the Hobbesian idea of the people.

Drawing eclectically on authors including Machiavelli, Nietzsche and Arendt, Honig's theory parallels Chantal Mouffe's influential theory of agonist democracy (see in particular Mouffe, 2000, 2013). Mouffe also speaks about a fundamental 'paradox', namely the impossibility of perfectly reconciling different logics that must however be reconciled and articulated in liberal democracies. What must be recognised, for Mouffe, is that democracy is first and foremost a place of and for conflict, a place that derives from, and incessantly produces conflictuality. Far from making an anarchist reading of political life, however, Mouffe claims that 
distinctions must be made between different kinds of conflicts, namely those that must be expunged and those that can and actually should be admitted within a pluralist, liberal, democratic society. Agonism should thus be distinguished from antagonism, with the former a moderate and acceptable form of pluralism, and the latter the degenerative and destructive element of politics.

Mouffe echoes here the arguments developed by early modern liberal philosophers engaged in justifying a framework for distinguishing good from bad conflicts, separating more moderate and less violent conflicts that can support the common understanding of political and economic actors from the more radical and violent conflicts that destroy the unity of the people. Machiavelli had already shown the aristocratic nature of this logic, denouncing as ideological the claim for a political reason that legitimises such a distinction (Del Lucchese, 2009b; see also McCormick, 2011). Apparently, Mouffe does not see any problem in applying this logic of partage to distinguish good and bad conflicts, nor does she say much about who would be authorised to create this discourse of power that produces entitlement or esclusion (see Rancière, 2004).

Mouffe's critique of the deliberative approach, which is exclusively based on reason and dialogue, raises the fundamental question of politics as conflict. However, she explicitly claims that the distinction between agonism and antagonism should be grounded on a prior process of legitimisation, or construction of the 'legitimate enemy'. Similarly to Loughlin's relational perspective, this does not look all that different from a weak version of the deliberative approach itself, insofar as it requires a pre-emptive agreement with our adversary, 'one with whom we have some common ground because we have a shared adhesion to the ethico-political principles of liberal democracy' (Mouffe, 2000, p. 102). Wenman has attempted to strenghten this approach by emphasising the constitutive dimension of agonistic practices (Wenman, 2003, 2013; see also Connolly, 2002, 2005). By doing so, he also challenges the idea of an absolute freedom of citizens to 'alter' the game's rules, and therefore the necessity to frame this freedom wtihin a constitution. This, however, corresponds once again to the attempt to preserve or save constituent power from itself, a position Spinoza dismisses as unrealistic.

From the point of view of political realism, these positions sound more utopian than democratic, and sometimes more mystical than theoretical, as when Mouffe (2000) speaks about democracy as the 'asymptotic approach ... to the regulative idea of a free unconstrained communication ..., as a good that exists as a good only as long as it cannot be reached' (p. 137). What Mouffe loses is precisely the sense that democracy, within and beyond its inception, namely its constituent moment, is a kratos exercised by a demos, as I will try to show in this article via Spinoza's theory of constituent power. Going back to the early modern authors such as Spinoza who thematised a radical, realist and conflictual idea of constituent power, allows us to avoid the shortcuts of a hidden idealism presented as a democratic critique of idealistic and deliberative rationalism. 
Although the early modern debate on constituent power develops only in the period of the French Revolution, some scholars, including Carl Schmitt and, most recently, Negri (1999), recognise the origin of the concept of constituent power in an earlier period, and in particular in Baruch Spinoza's thought. This, however, gives rise to a second paradox, concerning Spinoza's thought itself. Spinoza is known to have argued for a radical equivalence between power and right, according to his well-known formula jus sive potentia. If the right of each individual, both singular and collective, is for Spinoza its power, in a relation of co-essentiality, how can constituent power derive from his thought? How can a power that, by definition, is pre-ordered and superordered vis-à-vis right fit in Spinoza's scheme? Is not this anteriority and superiority of power over right incompatible with the immanence advocated by Spinoza?

My first thesis in this article is that Spinoza actually maintains a radical and original idea of constituent power, an idea that provides a solution for the paradox implicit in its modern definition. Spinoza's concept of jus sive potentia implies a redefinition of the relationship between factual and normative whereby it is not possible to imagine a relationship of priority or superiority between constituent power and constituted power. It is only through a radical immanence that one can confront the law's claim to obliterate constituent power. Spinoza's philosophy allows to clarify the paradox implicit in the traditional definition of constituent power.

My second thesis is that Spinoza is able to accomplish this theoretical operation of fundamental importance at the dawn of modernity only by the originality of his conceptualisation of the relationship between ontology and history. Interpreters such as Schmitt and Negri have recognised the presence of Spinoza in the genealogy of constituent power considering its modern definition. For this reason, they postulate a superiority of ontology to history. Such a hypothesis, though, not only does not solve the paradox of constituent power, but instead drags Spinoza into this paradox. I want to argue that, on the contrary, the nature of Spinoza's constituent power depends on an immanent co-implication of ontology and history.

After having briefly illustrated Schmitt's and Negri's interpretations, I will analyse the relationship between ontology and history in Spinoza in order to clarify his contribution to a theory of constituent power. I will develop my argument following three major themes of this theory: the argument of the free will of the constituent subject, that of the relationship between the factual and political moment on one side and the normative and legal moment on the other, and finally that of the role and status of the conflict that precedes, accompanies and exceeds the foundation of the political community.

\section{History and Ontology}

The emergence of the concept of constituent power as an absolute power upon which the constitutional life of a community is grounded is traditionally linked to the Abbe 
Sieyes's thought and his book Qu'est-ce que c'est le Tiers État? Such a foundation is more generally related to the French revolution (Zweig, 1909). Without denying the fundamental importance of the constitutional debates of the French revolution, twentieth century's historiography begins to recognise the role played by Spinoza in the modern genealogy of constituent power in the early years of the twentieth century. After Menzel (1929), Schmitt in his 1928 text on the Verfassungslehre places Spinoza at the heart of the problem concerning the foundation and validity of the legal constitution (Schmitt, 2008; on Spinoza and Schmitt, see Lauermann and Heerich, 1991; Walther, 1993, 1994, Castrucci, 1999). It is necessary, Schmitt argues against the jurists of his time, to distinguish the constitution (Verfassung) from Constitutional Law (Verfassungsgesetz) (Schmitt, 2008, p. 75ff). The validity of any law, intended as a normative tool, is based on the decision of a pre-existing political authority. Schmitt (2008) refers the essence of political authority to a major concept of Spinoza's philosophy, namely the conatus, the effort to strive to persevere in being (p. 76).

It is not the ethical-normative plan, but the factual and existential plan that underpins the political entity's 'right', and that lives and operates amid other entities in a network of relationships that potentially - and sometimes actually - are in conflict. The Spinozist in suo esse perseverare is summoned here. 'Each thing', Spinoza writes, 'insofar as it is in itself, endeavours to persist in its own being' (E III, P6). ${ }^{1}$ Spinoza identifies this effort with the thing's essence itself, which expresses the same power of God in a precise and determined way. Hence, this conatus expressing existence, insofar as it is referred to the political entity, receives its legitimation directly from the highest existing power, namely divine power, and does not require the mediation of any ethical and normative human value.

Still in the Verfassungslehre, Schmitt further specifies the analogy between Spinoza's concept of power, which plays an archetypal function, and constituent power itself as a historically concrete and original determination, inaugurated by Sieyes's work. The people, according to Schmitt, is the origin of every political event. It incessantly produces new forms of organisation, but its existence is never formed: a formative entity that is never definitively formed. Although this is only possible, historically, with the political rising of the French people in the actual conditions of the late eighteenth century, Sieyes's thought is explicitly reminiscent of Spinoza (Schmitt, 2008, p. 128).

In his 1921 work on dictatorship, Schmitt had already encountered Spinoza's metaphysics. In this book, he builds a distinction between the concept of 'Commissary Dictatorship', that is to say a juridical institute subordinated to and for the maintenance of the existing order, and 'Sovereign Dictatorship', a force that, on the contrary, creates a new right and a new order. The historical novelty is once again placed by Schmitt in the eighteenth century, with Rousseau and Sièyes. Again, however, the Spinozist matrix resurfaces and points to a different idea, namely a deviation from the mechanistic rationalism. Constituent power, as well as its 
metaphysical analogue, that is to say Spinoza's natura naturans, is not limited to the sphere of pure rationalism. On the contrary, Schmitt (2014) argues that 'from the infinite, incomprehensible abyss (Abgrund) of the force (Macht) of the pouvoir constituant, new forms emerge incessantly, which it can destroy at any time and in which its power is never limited for good. It can will arbitrarily. The content of its willing has always the same legal value like the content of a constitutional definition' (pp. 123-124).

Through this mystical language, Schmitt attempts to subtract Spinoza from the arid rationalism in which he thinks his thought is caught. Spinoza's philosophy is thus pushed towards a generative mysticism in which infinite forms arise from an unfathomable abyss. It is interesting to note that Schmitt reverses here Hegel's conclusion, albeit while borrowing Hegelian language. Hegel (1990) also talked about the 'abyss' of substance, an abyss, however, that swallows everything: 'with Spinozism everything goes into the abyss but nothing emerges from it' (p. 122).

Following somehow Schmitt on the ground of the unconditional production, Antonio Negri also ranges Spinoza at the heart of his reconstruction of constituent power, though he is careful to avoid a mystical reading. Negri (1999) situates Spinoza within an alternative and underground current of philosophical thought that leads from Machiavelli to Marx and, beyond Marx, towards a highly subjectivist conception of constituent power (p. 1). For Negri (1999), Spinoza's multitudo is the absolute subject that most faithfully embodies the concept of constituent power in his alternative history of Western metaphysics (p. 304). Negri's absolute is far from Schmitt's amorphous morphogenesis. Instead it reminds us of the idea of democracy as an absolute form of government (omnino absolutum imperium, in Spinoza's words).

Without embracing a vitalist or mystic approach à la Schmitt, Negri recognises an indisputable priority of the ontological dimension vis-à-vis the historical one. He thus raises democracy to the rank of divinity, albeit an atheist and materialist one: a divinity that expresses its attributes in the field of ontology before that of history (Negri, 1999, p. 305). The historicity and therefore the tensions, conflicts and limitations that characterise democracy as a historical practice of government are opposed to the ontological priority of puissance over pouvoir, and of constituent power over constituted power. As a consequence, the absolute nature of democracy is not found within the irregular and unsteady dimension of history, in which constituent power establishes itself against other powers. Democracy is an absolute form of government, for Negri, insofar as it is a metaphysical principle.

If one accepts the ontological priority suggested by Negri, one cannot escape the paradox implicit in the relationship between constituent power as a metaphysical entity and constituted power as a historical and legal entity. Constituted power is created by and derives from constituent power, and yet, the former necessarily obliterates the latter within the legal sphere. A similar problem emerges if one follows the mystical interpretation of Schmitt: the specific legal form that emerges 
from the abyss constituting all forms must necessarily absorb and subsume the political power that, through a pure and unconditional decision, has given life to it.

The question finds a better formulation in terms of the relationship between constituent principle on one side and constituted power on the other. The historical dimension has to be envisaged together with the ontological one. In other words, beyond the ontological purity argued by Schmitt and Negri, it is within the relationship between ontology and history that the problem of constituent power must be examined.

\section{Reason and Desire}

One of the main features of constituent power that modern theorists emphasise is that its free will is absolute. The free will expresses the determination to break with the past and to establish a new order and a new idea of justice. Rousseau, for example, focuses on the quasi-mystical passage from the will of all to the general will (see Del Lucchese, 2014b). For Sieyès, the nation itself is defined through a single will. A first major difference from Spinoza's conception thus emerges from the idea of a free and absolute will as characteristic of modern constituent power. In fact, one of the major objectives of Spinoza's philosophy is to destroy, in both the anthropological as well as the ontological dimension, the idea of a free will, as well as to denounce the aberrations arising from it.

To begin with, Spinoza's God has no free will. Reversing the traditional personalistic concept of the Judaeo-Christian theology, as well as the common sense around the idea of freedom, Spinoza's God only acts by the necessity of its own nature and, for this reason, it can be said free (E I, 17, C2; see also E I, 17, S). God, in other words, does not act like a king, as ignorant theologians believe (E II P3S). This analogy with kingship that Spinoza employs to redefine the idea of God also works in the other direction, that is, to deny that a king can be conceived through the analogy with divine omnipotence, or, as Hobbes would put it, like a mortal God. No political power therefore, including a constituent power, can be recognised as acting according to an absolutely free will, because to Spinoza such a will is simply an illusion.

Spinoza's analysis extends to his conception of man and, in particular, the mindbody relationship. He accuses Descartes of having inaugurated a revolutionary method without having been able to forsee all its consequences, and of having ultimately opted for absurd and incomprehensible assumptions (E V, preface). Against the Cartesian anthropology, Spinoza argues for the nonexistence of free will in the human mind (E II, P48), and maintains instead that the will, which is nothing but the intellect (E II, and P49C S), is not a free but rather a necessitated cause (E I, P32). This conclusion rules out every possibility of conceiving the relationship between the mental and the corporeal, the res cogitans and the res extensa, in terms 
of mutual influence and reciprocal power of one over the other, as it is for Descartes. The mind and the body, Spinoza argues, are both either active or passive, affecting and being affected at the same time in the same way.

The constituent power's absolute freedom is thus as inconceivable as any other entity's absolute freedom. Such freedom would establish a relationship between the constituent subject and the constituted object - the law or the formal constitution that would be analogous to the Cartesian model of mind-body relationship: a free people that, as an absolute subject, freely wants and freely determines what it wants, imposing a legal form on the matter of social relations. Nothing like that exists in Spinoza's philosophy. In the transition from the individual to the collective sphere, the will does not change its nature: the multitudinis voluntas only appears once in the Political Treatise and Spinoza does not devote special attention to it, referring it to the executive rather than the constituent power (PT VII, 25).

Spinoza is thus able to place reason on the same level as affects and oppose the abstractions of contractualist philosophers. Imagination becomes for him a cement that is sometimes stronger than reason itself in the process of the state formation Williams, (2007). Men 'conspire together either by reason of a common fear or through desire to avenge a common injury' (PT III, 9). This is often accompanied by a metus solitudinis, or fear of loneliness, that pushes men to strive for a political life in common. Against the chimera of will, therefore, Spinoza opts for a more complex interweaving between reason and desire. A desire that, despite the myth of unity and homogeneity, begins to reveal what remains hidden in modern constructions of constituent power, that is to say, its polemical and conflictual dimension.

\section{Before and beyond the Constituent Moment}

Modern theorists generally agree that constituent power is released from any legal obligation. According to Böckenförde (1991), the problem of constituent power's limitation cannot be posed in terms of a preceding 'right' that opposes it, because there is nothing legally prior to constituent power. Other limits and other obligations, however, exist for him: limits that come before and are above the process of law's constitution itself, in the sense that they express the tendency towards a legal order and the constitutionalisation of power. It is precisely the conformity to such ethical principles and extra-juridical normativity that gives legitimacy, in Böckenförde's view, to constituent power. Either constituent power conforms to them, or it is a mere destructive force with no connection with the juridical.

This perspective, however, does not overcome, but rather confirms the initial paradox. In fact, it intensifies the conflict on both the juridical and the ethical plains. With regard to the juridical, the paradox appears in the conflict between the constitution, which by definition is derived and posed (in the sense of a ius positum) by the legislator, and the values and ethical principles that constituent power means 
to establish (positive law versus ethics). How and when has constituted power been able to set itself free from the constituent power that is its only origin?

With regard to the second, or ethical, dimension, the paradox is even more serious. Constituent power entirely unfolds in the ethical dimension. It is therefore by definition legitimate in asserting its own values and principles against other values and principles, with no superior normativity to be consulted (ethics versus ethics). To what should it therefore comply? Who can judge the superiority of some ethical principles vis-à-vis other principles, without at the same time revealing - through the act of judgement itself - the necessarily contingent and therefore historical and factual nature of any ethical value?

This dilemma can be solved, in my view, via Spinoza's thought. One of Spinoza's major theses is the negation of any higher and transcendent principle that guides men's thoughts and actions from above. Those with a traditional conception of God and religion generally believe in these higher principles. But it is precisely here that we see the difference between the wise and the ignorant, and, as Deleuze has put it, between ethics and morality (Deleuze, 1968).

Spinoza begins by attacking the concepts of good and evil. As absolute principles, they are merely 'human fictions'. Spinoza replaces them with the concepts of useful and useless, emphasising their relativity and immanence vis-à-vis the desires, aversions, actions, and thoughts of individuals whom they refer to (E I, Ap, see Saar, 2013). Hence, in Spinoza's thought, there is not any anterior or superior value or principle that could work as an external and non-juridical boundary to the exercise of constituent power.

Spinoza's use of categories such as just (justus) and justice (justitia) also confirms this reading. Both the noun and the adjective have an astonishingly low frequency in Spinoza's lexicon, especially when compared with the imposing presence of the category of right (jus), understood as power (potentia), in its various meanings (see Giancotti, 1970). Justice is often conceived by Spinoza as nothing more than an attitude accompanying charity towards others. In a strictly political and legal sense, the concept of justice is significantly absent where one would expect to find it, namely in the contractualist argument of chapter XVI of the Theological-Political Treatise. Chapter XVI refers to chapter XIX which, along with other parts of the Ethics and the Political Treatise, acknowledges the existence of just and unjust only within the State and thus, for the purpose of our discussion, only downstream from the exercise of constituent power. A superior idea of justice is therefore not a main concern for Spinoza. There is no transcendence within his philosophy, not only on the juridical plain, but also on the ethical one: neither before, during, nor after the constituent moment can one find anterior or superior principles that may guide or externally limit constituent power.

And yet, as modern scholars have underlined, constituent power lies at the same time in the factual and in the legal dimensions. To fully grasp this idea, it is useful to consider the work of Italian jurist Costantino Mortati. Mortati (1972) speaks about a 
'normative fact': a paradoxical expression that seems to turn upside-down Hume's solution to the is-ought problem by locating the foundation of what legally ought to be in what factually is, without dismissing the normative dimension of the problem (p. 12). Implicitly following Spinoza, however, Mortati does not regard his normative fact as an amphibian concept with one foot in the factual and the other in the juridical, or as a mediation or a compromise. On the contrary, dissociating himself from contemporary jurists like Georg Jellinek, Santi Romano or Carré de Malberg, Mortati (1972) interprets the normative fact in the sense of the autonomy and, one might say, the esse sui juris, that is to say, 'a fact which has in itself its own law and the guarantees of its persistence in the future' (p. 12).

Mortati's normative fact is of pivotal importance in grasping constituent power's nature as something that is at the same time political and legal. It is through Spinoza, however, that such an idea becomes fully consistent and avoids the paradox of the traditional relationship between constituent and constituted power. Constituent power has in itself its own law, and the multitude that exercises it is free and fully sui juris insofar as it autonomously establishes those laws: it is sui juris, once again, not in the sense of a justus, but in the sense of a jus sive potentia (see Balibar, 1985; Montag, 2005; Morfino, 2014).

Spinoza's definition of subject and sovereign also confirms this conclusion. The subject is the individual who obeys, whatever the reasons for this obedience: Non enim ratio obtemperandi, sed obtemperantia subditum facit (TPT XVII). This conclusion is mirrored by the other for which oboedientia facit imperantem: a maxim that is not found in Spinoza, but that was attributed to him much later, and is regularly quoted as the ground of any imperative theory of law (see Radbruch, 1914; Preuß, 1921; Heller, 1927; or Jellinek, 1931). This maxim is still at the heart of modern conceptions of effectiveness and justification of constituent power (Mortati, 1972, p. 51). Like any other individual, Spinoza argues, the sovereign exercises his right to rule only insofar as he also has the power to do so. This is what Matheron (1984) has called a 'instantaneous consensus', distinguished from the 'integral consensus' of Grotius, Hobbes and other classic authors of contractualism. Sovereign and subject are thus mutually defined, in and through a force relationship, without the primacy of a principle of authority but rather following the variations in the level of rationality and usefulness of each given command (Bove, 1996).

Legally, the sovereign holds an absolute right to order whatever he wishes. Factually, however, such a right does not exceed his actual power, not only in relation to the agent, but also to the patient, according to the well-known passage from Political Treatise, IV, 4. The same is true for constituent power. Formally, it is in a situation of absolute freedom, but from a factual point of view, it acts and operates in a specific historical context.

Having in itself its own law and the guarantees, at once factual and juridical, of the persistence in its own being means having the power, and therefore the right, to act and operate according to its own nature. Here lies the autonomous character of every 
power, individual and collective. The principle of jus sive potentia, once again, characterises every single individual, including the sovereign and the constituent subject. Spinoza reaches the radicality of this position not by undermining the concept of law, but on the contrary by 'allowing it to say everything that it is able to say' (Matheron, 1984).

'Jura sunt', Spinoza writes, 'anima imperii' (PT X,9). If a State can be said to be eternal, it is because its jura remain intact. This passage has challenged our best translators. Jura has been translated by legislation, laws, constitution, rule of law, and the rights themselves. Rarely, in Spinoza's lexicon, have the options been so divergent. What is Spinoza suggesting when he says that the jura are the anima imperii? I think that he is applying to the problem of the relationship between politics and law the same solution through which he thinks the radically immanent relationship between soul and body. The jura does not lead the state from above, and does not act on the positive law from above, in the same way that the mind does not guide the body from a superior position.

Vis-à-vis the present discussion, however, I think that one can say something more. The soul of the imperium is not the constitution, as some translators suggest. It is not even the emperor himself, as suggested by several classical authors, including Tacitus (1931, I,12, pp. 266-267), Seneca (1928, I,III,5, pp. 366-367), or Florus (1929, II,XIV,6 pp. 300-301). My hypothesis is that Spinoza means something very close to the principles, at the same time factual and normative, legal and political, that precede, accompany, and go beyond the formation of the state. He means something similar, in a word, to constituent power: a living power that animates and constitutes the juridical, on both the factual and the normative field:

If any State can be eternal, it must be one whose jura, being once correctly established, remain inviolate. For the jura are the anima imperii; if they are preserved, the State is preserved. But the jura cannot stay intact unless they are defended both by reason and by the common affects of men; otherwise if they are dependent solely on the support of reason, they are weak and easily overthrown.

Spinoza raises the question of the adequacy of constituent principles (jura fundamentalia) to the actual development of political life. The historical case of dictatorship, recalled by Spinoza in the paragraph that follows the quote above, is notable. Spinoza emphasises that laws are sometimes destroyed even if they are protected by reason and the common affects. This happens in particularly critical situations when the state itself is under the action of external or internal forces that threaten it. All, then, look for a man 'renowned for his victories' to become dictator, trusting in his exceptional intervention to restore normality (PT X,10). This is precisely what led to the loss of Roman freedom.

In his analysis of dictatorship, Spinoza is precisely conceptualising constituent power, as Schmitt also recognises. Through sovereign dictatorship, Schmitt suggests, 
a constituent principle rises from within the constitutional life of the State. This principle is closely related, following Schmitt's (1996) famous formulation, to the definition of the sovereign as the one who decides in the state of exception.

Spinoza also argues that dictatorship heavily impacts on the question of sovereignty. His conclusion, however, is opposed to Schmitt's, because for Spinoza the juridical institute of dictatorship inevitably destabilises the constitutional order currently in place. A state tendentially eternal, on the contrary, is for Spinoza the one in which constituent power remains alive, without transcendentally guiding the State, but rather on a plane of immanence and coexistence with it.

Such a solution, however, prevents a peaceful relationship between the constituent and constituted moments. On this plane of immanence, the same exceptional and conflictual historical situation that opened the constituent period moves, so to speak, within the juridical and imposes a new role for the phenomenon of conflict, both externally, vis-à-vis other states, and internally, between the multitude and the sovereign.

\section{Conflict against Power and Conflict for Power}

In the dialectic between the factual and the normative, modern interpreters have questioned the possibility of developing a theory of constituent power, given the multiplicity of historical situations upon which the concept is grounded. If constituent power, Mortati (1972) asks, is the expression of a supreme will, if it is pure factuality, and hence subject to virtually endless variations, how can one develop a scientific study of it? Mortati suggests the need for a study of constituent power at the same time historical and theoretical, in order to grasp its 'necessary and therefore constant forms', but also its 'concrete singular realisations' and 'historical typologies'.

But Spinoza, for whom the ontological level is never separable or separated from the historical one, had already made such a study. With his own historical situation in mind, namely the conflict between the United Provinces and Louis XIV's France, Spinoza analyses the problem of constituent power through two concrete examples. Each situation has its own characteristics from which, however, it is possible to draw general conclusions.

The first historical case is the story of the exodus and the liberation of the Hebrews by Moses. Spinoza introduces the unique history of this nation with an explicit reference to two alternative conceptions of constituent power, which will be eventually developed during and after the French revolution. Traditionally, the ground of sovereign authority, absolute because unfounded and thus entirely independent, was divine authority. This is why it has been maintained that the origin of constituent power is to be found in the secularisation of theological attributes and divine authority. Spinoza, on the contrary, shows that divine authority is nothing 
more than an imposture employed by sovereigns to stabilise their regimes. They have always tried to make people believe that majesty 'is established by God, not by the votes and consent of men, and is preserved and sustained by God's special providence and help' (TPT XVII). For Spinoza, the ground of constituent power's authority and its attributes are to be found in the entirely human history, unique and yet paradigmatic, of the Jewish people.

The characteristic of the Jewish people after the exodus is that they consider civil law and religion one and the same thing. To God alone, in fact, they have promised to be faithful and they have fully transferred their power to him, and therefore their rights, making him their sovereign. It is not the power of the Hebrews that depends on God, but rather the power - and therefore the right - of God, qua sovereign, that depends on their decision, after they follow Moses's advice. They form a 'theocracy', which corresponds in reality, according to Spinoza, to a democracy.

In the beginning, then, all the people went before God, their legitimate sovereign. However, crushed by his voice and fearing death, they decided to transfer the exclusive right to interpellate God and interpret his commands to Moses. Spinoza adds that this is indeed a 'second pact', one that abrogates the first. Constituent power is with the people, who confer all their power on Moses, who could have legitimately used it to transform the theocracy to a monarchy. Instead, after his death, this power is separated into the administration of public affairs, the division of land and the attribution of the respective powers to the different tribes. The original relationship between the people and God remains intact, and God is confirmed as the true sovereign.

That the question of law (that is to say, of its legitimacy, its authority and its validity) is always already a matter of fact is demonstrated by experience and reason (see Moreau, 1994). It is shown first, for Spinoza, by the crucial dimension of the armed Jewish people, which is the true foundation of their liberty and resistance to corruption. No other organisation, institution or custom is so powerful as the army in keeping the Hebrews attached to their traditions and freedom. Following Ezra, and using a dazzling expression, Spinoza calls Jerusalem a civitas rebellis, a rebel city (TPT XVII). Jerusalem did not and does not recognise any superior force. It is therefore not, strictly speaking, a return to war, but rather an intrinsic link that law maintains with war, or rather that the Hebrews maintain with their original power, that is, their constituent and factual power. This is essentially a warlike power, in the double sense of being in conflict against anyone else, and being defended by force and by the free citizens' army.

In the last part of the chapter, Spinoza explains the causes of the collapse of the Jewish State, through the introduction of the Levites' privilege. The original democratic theocracy is corrupted by the introduction of an element of privilege that takes the place of the original equality. Thus the new constituted power clashes with the constituent power from which it was generated. Constituent and constituted power diverge and corruption gradually weakens the State's original strength. 
When the original popular government is transformed into a monarchy, which is not suitable for the people's ingenium, everything collapses (TPT XVIII).

The second historical example, as complex as the first one, is that of the Aragonians, illustrated in Political Treatise VII,30. Spinoza's main source is Perez (1644), former secretary of Philip II. Closely following his source, Spinoza speaks of the birth of the legendary fueros aragonenses, the privileges of the Aragonians vis-àvis the King of Spain (Magoni, 2007). After the expulsion of the Moors, the Aragonians found themselves in a situation quite similar to that of the Jews after the exodus. They decided to create a king and seek the advice of Pope Gregory VII. The Pope suggests that they follow the example of the Hebrews, who had avoided creating a monarchy. But, he adds, if they really want a monarchy, it should at least be constituted with certain conditions. Thus the Aragonians establish a council, led by the Justicia. Randomly appointed (the ultimate democratic mechanism), the council had the right to oppose the sentence of any court, and even of the king himself. It is thus a real counter-power, whose authority derives directly from the constituent power of the Aragonese people.

This council's highest authority was the power to appoint and depose the king, according to the apocryphal formula 'Nos qui valemos tanto come vos, y podemos mas que vos, vos elegimos rey' (Being as praiseworthy as you are, and more powerful than you, we appoint you king). And it is precisely with the abolition of this absolute power that the gradual normalisation of the Aragonese anomaly begins. After the initial conflict with Pedro IV in the mid-fourteenth century, the people's privileges will progressively be abolished under Ferdinand of Aragon, Philip II and, finally, Philip III, under whose reign the Aragonians retain 'nothing but the plausible names and empty forms of freedom' (PT VII, 30). Again, as for the Jews, Spinoza tells the story of a constituent power that is gradually absorbed and expropriated within a constitution that separates the subjects from their own natural power.

However, the story of the first conflict between the subjects enjoying the fueros aragonenses and King Pedro IV reveals the precariousness that characterises any new legal construction. King Pedro, in Perez's account, stages the solemn destruction of the document establishing the privileges. He cuts the document with a knife, hurting at the same time his hand, to indicate that only by shedding blood may a king be subject to a people. The fueros are thus eliminated, provided, Spinoza adds, that subjects could 'take up arms against any violent action whereby anyone may seek to encroach on their dominion to their hurt, yea, even against the king himself and the prince, his heir, if he thus encroaches (on their dominion)' (PT VII, 30).

This is a meagre condition, one could say, for those who have just lost their privileges. Yet Spinoza adds here a reference, explicit and direct, to the jus belli, the law of war that always exists between subjects and sovereign. 'As we have shown in Sections 5 and 6 of Chapter IV', he says, 'it is not by civil right but by right of war that a king can be deprived of his power to rule; in other words, it is by force alone that his subjects may resist his force' (PT VII, 30). Conflict comes to the foreground 
once again, as the underlying dimension of any relationship of domination and any configuration of balance between constituent power and constituted power, according to the principle that Spinoza uses to govern the whole argument, namely the strict equivalence between jus and potentia.

Through these two historical examples, Spinoza evokes a third, possibly more complicated and certainly more urgent situation, that is, the Low Countries of his own time. Zourabichvili (2002) highlighted the similarity between the Aragonese regime and the United Provinces during the struggle between the Regents and the Count, before the Orangist triumph in 1672. Spinoza wrote the Political Treatise in a country under occupation, trying to identify the conditions for a resistance and an ultimate effort to defend liberty. It is only through a struggle for freedom that the multitudo will be able to reopen the constituent process. In line with the historical examples cited, however, Spinoza also develops the argument he learned from the acutissimus Machiavelli, namely that the external conflict is always also an internal conflict. The free multitude tends towards the most stable and absolute regime, namely democracy, by fighting against the privileges of a group (as the Hebrews against the Levites) or a single individual (as the Aragonese people against the king Pedro IV).

Only in this way, that is, through history, Spinoza is able to build an ontology of constituent power. On this basis, Spinoza develops a critical analysis of the traditional forms of government, and strongly maintains his opinion of the superiority of democracy as the only absolutely absolute imperium. Only in democracy is the highest level of collective power - and therefore right - attained, because "the greater the number of men who thus unite in one body, the more right they will all collectively possess' (PT II, 15 and PT II, 13; see Sharp, 2007, 2011).

The question of monarchy and aristocracy is, however, more complex. The problem becomes, for Spinoza, the relationship between the multitude's constituent power and the constituted form of government. In both monarchy and aristocracy, Spinoza identifies a constitutive right of resistance that continually generates a conflict between the multitude and the sovereign (see Bove, 2002; Del Lucchese, 2009a).

A monarchy, to begin with, is never really that, because one man cannot support the entire weight of the State. The monarchy is always in fact a hidden aristocracy. The sovereign's right to command the subjects is here based on his power to do so, as it is the case for any individual that commands to any other individual, singular or collective, in Spinoza's universe. While the subjects fear and respect him, the sovereign has the right to govern, for he has full power to do so. Once fear and respect disappear, wiped away by indignation, his right collapses, because his power vanishes. The rules do not depend on public law, but on natural law, because they can only be guaranteed by a right to war (PT IV, 5).

The aristocracy seems to be a more stable form of government, because sovereignty lies in a collective body, and is thus immune to the oscillations of a 
mortal being. In praxi, however, the systematic exclusion of the multitude from government creates the conditions for a latent and constant conflict against the sovereign. This form of government is not absolute because 'the multitude is an object of fear to the rulers, thereby maintaining some degree of freedom for itself, which it asserts and preserves, not by express law, but by tacit understanding' (PT VIII, 4). Jus multitudinis against jus imperii.

A twofold conflict, then, appears in Spinoza's theory: conflict against power, and conflict for power, when power is not democratically organised and equally shared. Positioning Spinoza in line with Hobbes and Bodin and within the State sovereign paradigm, as, for example, Kalyvas (2005) does, is in this sense a serious mistake. Moreover, it encourages the dubious reading of constituent power as a homogeneising and fundamentally centripetal force. Kalyvas goes so far as inventing a doubtful etymology for constituent power: the prefix con-, he says, refers to the Latin cum-, with the meaning of being with, being together. Thus, for him, 'the word constituere ... literally denotes the act of founding together, founding in concert, or creating jointly' and 'the constituent power points at the collective, intersubjective ... attribute of sovereignity, at its cooperative, public dimension' (Kalyvas, 2005, pp. 235-236). I have not been able to find any support for Kalyvas's etymological interpretation. The com- of constituere is in fact an intensive prefix that reinforces the idea of setting up, fixing, and establishing things together (see TLL, 1900-1906). 'Together' cannot be taken in a subjective sense, as Kalyvas suggests (that is, different subjects acting together, in concert or jointly), but only in an objective sense (that is, a subject that organises, constitutes and puts together different objects).

The idea of conflict, thus, regards the constituent power against the constituted power but also, and here, concisely, is my thesis, conflict within constituent power itself. Constituent power is based on a structural dissension and, instead of neutralising it in the juridical, it moves it within the constituted dimension.

\section{Conclusion}

Spinoza anticipates one of the fundamental problems of modern constituent power, namely its reactivation within the law when the material configuration of society no longer corresponds to its initial project. Spinoza also offers a new perspective on this problem through his conception of jus sive potentia. For this reason he insists on the importance of keeping alive the constituent principles, the jura fundamentalia: the only way to avoid violent revolutions is to maintain a state of permanent revolution, namely a situation in which the juridical does not detach itself from the factual from which it arises, but instead gives it life, in and through collaborative and conflicting relationships among subjects.

Mortati's conclusions, once again, are close to Spinoza's. Constituent power, Mortati argues, arises from the disharmony between the different interests frozen in 
the positive law and the existing power relations on the one hand, and what he calls the infinite process of criticism and desire for more justice on the other. Such a desire inevitably grows when the old order's capacity to adapt to a new situation has reached its limit or, as Spinoza would put it, when fear becomes indignation (PT IV, 6). Thus a process of adaptation begins, which reveals its partiality and conflictuality, and in which new values and principles - new jura - come forward to establish a new order.

The validity of these principles is self-grounding, that is to say autonomously legitimate without the need for any external justification. Spinoza had explained this clearly to Jarig Jelles: 'I always preserve the natural right in its entirety (naturale Jus semper sartum tectum conservo)' (Letter 50). The jura that bind together the factual and the normative, the constituent and the constituted, are powerful if and only if they are protected by reason and affects. When modern theorists argue that such principles are immutable, eternal and super-ordained because they are inspired by reason, they end hypostasising reason itself. Again, with a strong Spinozist tone, Mortati suggests instead that these principles are perhaps immutable only for the subject that can fully grasp the whole rationality of nature, in a comprehensive and universal way. But such a being is not human; in fact, in a Spinozist sense, it is none other than God.

To both Mortati and Spinoza, therefore, the reference to natural law means the historical realisation and relativisation of the search for the jura most suitable to the new order. Constituent power is not, in this sense, an absolute subject or an absolute power. It is rather a historically determined subject and a power, within the here and now of material relations of power, those it follows as much as those it is able to create: against the absolute monarchy in 1789, against fascism in 1945 and so on. Constituent power can only be seized historically, on the plain of the immanent relationship between politics and law, as well as between ontology and history.

Following Spinoza, therefore, one cannot postulate the priority and superiority of constituent power over constituted power, no more than one can postulate the superiority of potentia over jus, or of substance over modes. Imagining such a superiority is certainly possible, but only because our imagination is both powerful and misleading. Constituent power and constituted power are just two aspects of the same reality.

\section{About the Author}

Filippo Del Lucchese is senior lecturer in the history of political thought at Brunel University, Uxbridge, London, Senior research associate at the University of Johannesburg, and chair at the Collège International de Philosophie in Paris. His research interests are in the early modern period (from the Renaissance to the Enlightenment), history of philosophy and Marxism. He has been a Marie Curie Fellow, and holds degrees from the universities of Pisa and Paris IV (Sorbonne). 
He is the author of Conflict, Power and Multitude in Machiavelli and Spinoza (Continuum, 2009) and The Political Philosophy of Niccolò Machiavelli (Edinburgh University Press, 2015). He has also published articles on the history of early modern philosophy and political theory in journals such as History of Political Thought, European Journal of Political Theory, Dialogue, International Studies in Philosophy, and Differences.

\section{Note}

1 I have occasionally modified Shirley's translation for greater accuracy. I will hereafter use the following abbreviations to cite Spinoza's works in the text (Spinoza, 2002): Ethics =E, Theologico-Political Treatise $=T P T$, and Political Treatise $=P T$. All roman numerals refer to parts or chapters. In the case of the TPT and the $P T$, numbers refer to paragraphs. When referring to citations in the Ethics, I will not use page numbers, but instead the following abbreviations to signify the location of quotes: Axiom = A, Definition $=$ D, Proposition $=$ P, Scholium $=$ S, Corollary $=$ C, Appendix $=$ Ap, Postulate $=$ Post.

\section{References}

Balibar, E. (1985) Spinoza et la politique. Paris, France: Presses Universitaires de France.

Böckenförde, E.W. (1991) Die verfassunggebende Gewalt des Volks. Ein Grenzbegriff des Verfassungsrechts. Frankfurt am Main, Germany: Suhrkamp Verlag.

Bove, L. (1996) La Strategie du conatus. Paris, France: Vrin.

Bove, L. (2002) 'introduction à B. Spinoza'. In: B Spinoza Traité Politique. Paris, France: Librairie Générale Française.

Castrucci, E. (1999) Genealogie della potenza costituente. Schmitt, Nietzsche, Spinoza. Filosofia politica 2(2): 245-251.

Colón-Ríos, J. (2012) Weak Constitutionalism: Democratic Legitimacy and the Question of Constituent Power. London, New York: Routledge.

Colón-Ríos, J. (2014) Five conceptions of constituent power. Law Quarterly Review 130: 306-336.

Connolly, W.E. (2002) Identity/Difference: Democratic Neogtiations of Political Paradox. Minneapolis, MN: University of Minnesota Press.

Connolly, W.E. (2005) Pluralism. Durham, NC: Duke University Press.

Deleuze, G. (1968) Spinoza et le problème de l'expression. Paris, France: Les Editions de Minuit.

Del Lucchese, F. (2009a) Conflict, Power, and Multitude in Machiavelli and Spinoza: Tumults and Indignation. London: Continuum.

Del Lucchese, F. (2009b) Crisis and power: Economic, politics, and conflict in Machiavelli's political thought. History of Political Thought 30: 75-96.

Del Lucchese, F. (2014a) Machiavelli and constituent poewer: The revolutionary foundation of modern political thought, European Journal of Political Theory, advance online publication 25 July, doi: $10.1177 / 1474885114544911$.

Del Lucchese (2014b) Freedom, equality, and conflict: Rousseau on Machiavelli. History of Political Thought 35(1): 29-49.

Florus, L.A. (1929) Epitomae de Tito Livio bellorum. London: William Heinemann Ltd.

Frank, J. (2010) Constituent Moments: Enacting the People in Postrevolutionary America. Durham, NC: Duke University Press. 
Giancotti, E. (1970) Lexicon Spinozanum. the Hague, the Netherlands: Martinus Nijhoff.

Hegel, G.W.F. (1990) Lectures on the History of Philosophy: The Lectures of 1825-26, Vol. III, Medieval and Modern Philosophy. Berkeley, CA: University of California Press.

Heller, H. (1927) Souveränität. Berlin, Germany: de Gruyter.

Honig, B. (1993) Political Theory and the Displacement of Politics. Ithaca, NY: Cornell University Press.

Honig, B. (2009) Emergency Politics: Paradox, Law and Democracy. Princeton, NJ: Princeton University Press.

Jellinek, W. (1931) Grenzen der Verfassungsgesetzgebung. Berlin, Germany: Julius Springer.

Kalyvas, A. (2005) Popular sovereignity, democracy, and the constituent power. Constellations 12: 223-244.

Keenan, A. (2003) Democracy in Question: Democratic Openness in a Time of Political Closure. Stanford, CA: Stanford University Press.

Lauermann, M. and Heerich, T. (1991) Der Gegensatz Hobbes-Spinoza bei Carl Schmitt. Studia Spinozana 7: 97-160.

Loughlin, M. and Walker, N. (eds.) (2007) The Paradox of Constitutionalism: Constituent Power and Constitutional Form. Oxford: Oxford University Press.

Loughlin, M. (2014) The concept of constituent power. European Journal of Political Theory 13(2): 218-237.

Magoni, C. (2007) Fueros e libertà. Il mito della costituzione aragonese nell'Europa moderna. Roma, Italy: Carocci.

Matheron, A. (1984) Spinoza et la problématique juridique de Grotius. Philosophie 4: 69-89.

McCormick, J. (2011) Machiavellian Democracy. Cambridge, UK: Cambridge University Press.

Menzel, A. (1929) Beiträge zur Geschichte der Staatslehre. Wien; Leipzig: Hölder-Pichler-Tempsky.

Montag, W. (2005) Who's afraid of the multitude? Between the individual and the state. South Atlantic Quarterly 4(4): 665-673.

Moreau, P.-F. (1994) Spinoza. L'expérience et l'éternité. Paris, France: Presses Universitaires de France.

Morfino, V. (2014) Plural Temporality: Aleatory and Transindividuality between Spinoza and Althusser. Leiden, the Netherlands: Brill.

Mortati, C. (1972) Studi sul potere costituente e sulla riforma costituzionale dello Stato, Raccolta di Scritti, Vol. 1. Milano, Italy: Giuffrè.

Mouffe, C. (2000) The Democratic Paradox. London: Verso.

Mouffe, C. (2013) Agonistics: Thinking the World Politically. London: Verso.

Näsström, S. (2007) The Legitimacy of the People. Political Theory 35(2): 624-658.

Negri, A. (1999) Insurgencies, Translated by M. Boscagli. Minneapolis, London: University of Minnesota Press.

Perez, A. (1644) Obras y Relaciones. Geneva, Switzerland: Por Juan de Tornes.

Preuß, H. (1921) Die politische Erneuerung. Berlin; Leipzig: Rotschild.

Radbruch, G. (1914) Grundzüge der Rechtsphilosophie. Leipzig, Germany: Quelle \& Mayer.

Rancière, J. (2004) Disagreement: Politics and Philosophy. Minneapolis, MN: University of Minnesota Press.

Saar, M. (2013) Die Immanenz der Macht. Politische Theorie nach Spinoza. Berlin, Germany: Suhrkamp Verlag.

Schmitt, C. (1996) Political Theology: Four Chapters on the Concept of Sovereignty, Translated G. Schwab. Chicago, IL: University of Chicago Press.

Schmitt, C. (2008) Constitutional Theory, Translated by J. Seitzer. Durham, London: Duke University Press.

Schmitt, C. (2014) Dictatorship, Translated by M. Hoelzl and G. Ward. Cambridge, UK: Polity Press. Seneca (1928) De claementia, in Moral Essays, Vol. 1. Cambridge, MA: Harvard University Press.

Sharp, H. (2007) The force of ideas in Spinoza. Political Theory 35(6): 732-755.

Sharp, H. (2011) Spinoza and the Politics of Renaturalisation. Chicago, IL: Chicago University Press. 
Spinoza, B. (2002) Complete Works, Translated by S. Shirley. Indianapolis, IN: Hackett Publishing Co. Tacitus, (1931) Ab excessu divi Augusti libri, in Annals. Cambridge, MA: Harvard University Press. TLL (1900-1906) TLL - Thesaurus Linguae Latinae. Stuttgart, Germany: Teubner.

Walther, M. (1993) Carl Schmitt et Baruch Spinoza. In: O. Bloch (ed.) Spinoza au XIXème siècle. Paris, France: Presses Universitaires de France, pp. 361-373.

Walther, M. (1994) Carl Schmitt contra baruch Spinoza oder Vom Ende der politischen Theologie. In: H. Delf, H.-J. Schoeps and M. Walther (eds.) Spinoza in der europäischen Geistesgeschichte. Berlin, Germany: Heintrich, pp. 422-441.

Wenman, M. (2003) 'Agonistic Pluralism' and three archetypal forms of politics. Contemporary Political Theory 2(2): 165-186.

Wenman, M. (2013) Agonistic Democracy: Constituent Power in the Age of Globalisation. Cambridge, UK: Cambridge University Press.

Williams, C. (2007) Thinking the political in the wake of Spinoza: Power, affect, and imagination in the ethics. Contemporary Political Theory 6(3): 349-369.

Zourabichvili, F. (2002) Le conservatisme paradoxale de Spinoza: enfance et royauté. Paris, France: Presses Universitaires de France.

Zweig, E. (1909) Die Lehre vom pouvoir constituant. Ein Beitrag zum Staatsrecht der französischen Revolution. Tübingen, Germany: J.C.B Mohr.

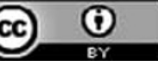

This work is licensed under a Creative Commons Attribution 3.0 Unported License. The images or other third party material in this article are included in the article's Creative Commons license, unless indicated otherwise in the credit line; if the material is not included under the Creative Commons license, users will need to obtain permission from the license holder to reproduce the material. To view a copy of this license, visit http://creativecommons. org/licenses/by/3.0/ 